\title{
Degree of internationalization and financial performance of gaming businesses: A study of CD Projekt capital group
}

\author{
Sławomir Szwajkosz
}

\begin{abstract}
A B S T R A C T
Objective: This article aims to evaluate the impact of the internationalization process of firms on their financial situation. Through the research process presented in this study, I verify whether financial analysis can have its legitimate application in assessing the internationalization of a firm in the gaming industry. This verification is done on the example of the CD Projekt capital group. The process of scientific reasoning in this paper will bring closer to the fulfilment of the main research objective - to answer the question about the desirability of applying ratio analysis in the research domain of internationalization of firms.

Research Design \& Methods: This paper applies an indicator analysis. Over the years of development of this analysis, researchers separated, measured, and formed the four most essential elements of its financial functioning to enable their evaluation. Using the literature on the subject, calculating tools and my knowledge, I independently prepared and developed eleven indicators that constitute the foundation of the research process presented in this article. The indicators will verify the hypotheses posed through calculations and interpretation of correlation coefficients between variables.
\end{abstract}

Findings: The effect of partial or complete confirmation of the hypotheses adopted in the introduction is to confirm that the company's internationalisation in the gaming industry has a positive impact on its financial condition. The result of the study is also the conclusion that the company's internationalisation has had a positive impact on almost every aspect of the CD Projekt capital group's operations and its current position is directly attributable to the internationalization process.

Implications \& Recommendations: To simplify the analysis, topic has been reduced to the example of a company in the gaming industry. I note, however, that the indicator analysis also seems to be a tool to assess the process of internationalization within other separate industries or sectors and therefore recommends further study of the issue.

Contribution \& Value Added: The use of indicator analysis in the research domain of the internationalization of enterprises has been the subject of scientific studies for some time. However, the attempt to implement the issue in the specificity of the creative industry is, according to the state of the author's knowledge, a kind of novelty. This work aimed to assess the impact of the internationalization process of a company in the gaming industry on its financial position. This goal was achieved, which confirms, following the principle of deductive reasoning, that assessing the impact of the internationalization process of the company based on indicator analysis retains economic sense.

\begin{tabular}{llll}
\hline Article type: & research article & \\
& indicator analysis; internationalization of firms; financial performance; international \\
Keywords: & business; gaming business; creative corporate finance & & \\
JEL codes: & F23, L23 & & \\
\hline \multicolumn{1}{c}{ Received: 2} & September 2021 & Revised: 15 November 2021 & Accepted: 18 November 2021 \\
\hline
\end{tabular}

\section{Suggested citation:}

Szwajkosz, S. (2021). Degree of internationalization and its financial performance of gaming businesses: A study of CD Projekt capital group. International Entrepreneurship Review, 7(4), 51-63. https://doi.org/10.15678/IER.2021.0704.04 


\section{INTRODUCTION}

Entrepreneurship is a social as well as an economic phenomenon, and attitudes and perceptions are important influences on the nature and level of that entrepreneurship(Global Enterpreneurship Monitor, 2021). The result of a global attitude and the ability to see an opportunity to grow a business regardless of where that opportunity arises is a shift in weight from focusing on the deepest possible market penetration to diversifying risk by operating in as many markets as possible. In reviewing the theory of internationalization, one may think that only manufacturing companies can benefit from internationalization. However, in this paper, I will prove that creative industries, including game business, which can be considered as most susceptible to internationalization factors, can also use internationalization instruments to improve their financial performance.

The objective of this article is to evaluate the impact of the internationalization process of firms on their financial situation. In this paper, I present and evaluate the assessment of the impact of the internationalisation process of a company from the innovative computer games industry, using a case study of the leader of the computer games market in Poland, listed on the Warsaw Stock Exchange CD Projekt Capital Group. I will evaluate the impact of the internationalisation process by using the structure of the ratio analysis of the company, proposed in Security Analysis (Graham \& Dodd, 2009), and relating changes in indicators determining the firm's financial position to changes in the geographical structure of income. The ex-post analysis will be based on ten consecutive reporting periods and will allow us to capture changes that may only become apparent in the long term.

Studies conducted in the literature on the subject, aimed at capturing the impact of the company's internationalisation on its financial performance, seem to be limited only to industrial companies (Barłożewski \& Trąpczyński, 2021; Chalmers et al., 2020; Steinbruch et al., 2020; Trąpczyński, \& Halaszovich, 2021). This action is understandable since industry represents a conservative, understandable business whose influence on the world economy was undeniable. Today, however, it is services that are becoming the backbone of the modern economy. Offshoring and outsourcing seem to be the cause of economic growth and development for many countries such as India, the Philippines or Vietnam (Cushman \& Wakefield, 2015), rising to the first position in outsourcing services due to rising labour costs in China. Therefore, I will focus on the industry directly related to the creative sector and digital technologies being the future of today's globalised economy (Maciejewski \& Głodowska, 2020; Rymarczyk, 2020).

The article consists of three main parts. It begins with a literature review and an indication and description of the research methodology. I will then focus on presenting and discussing its results. The conclusion, which will falsify or confirm the hypotheses articulated in the introduction, will constitute the last part of this paper.

\section{LITERATURE REVIEW}

The extant literature is rich in various theories, models and concepts explaining internationalization of the firms (Wach, 2021), however the leading position belongs to management theory and economic theory, while the financial theory lags behind. International expansion is a crucial decision for firms that regularly face transitional payment problems and concentrate their activities mainly on their home market (Ketels, 2016) and it is extremely import for young innovative firms (Wach, 2016).It affects small and medium-sized enterprises (SMEs), i.e., firms with no or relatively little international experience. It constitutes for them a kind of barrier to entering new markets. As a result, they interpret international activity through the prism of the costs it generates, often forgetting that the initiation of internationalisation processes is associated with a range of benefits, such as risk diversification, economies of scale or protection against market fluctuations or changes in trends, which often become the cause of liquidity problems for the company. Based on several studies, including those presented by the Ahroni's thesis (Ahroni, 1966), foreign investments generally are perceived as bearing a much higher risk than domestic investments due to the limited availability of information about foreign markets and the higher cost of obtaining information about the home market. The prospect theory, in turn, 
suggests that a company's financial performance correlate negatively with its willingness to take risks (Kahneman \& Tversky, 1979). It means that when a company meets the performance targets set by decision-makers, they are inclined to choose many lower-risk strategies to maintain their profits. It illustrates a situation in which, on the one hand, managers who achieve tangible benefits are not willing to take risks associated with the process of internationalisation. However, on the other hand, when the company's financial situation forces its executives to react. They, due to low international awareness, do not use the opportunities guaranteed by international markets and do not initiate internationalisation. However, the prospect theory complements the extremes related to the entity's financial situation, i.e., high liquidity and unprofitable activity, consistently assuming that the worse its result, the more risk it is willing to take. If the company characterises over-liquidity, it will be more willing to look for places to invest its capital (Jung \& Bansal, 2009). In the first case, when results are lower than expected, managers will evaluate current strategies and, as losses escalate, will accept a higher level of risk. In the opposite situation, they will regard internationalisation as an investment - forgoing the distribution of today's profits favouring future and uncertain profits. This observation provides the basis for the thesis of a relationship between internationalisation and company performance, but one can only speak of correlation, not causation, at this stage of the study of the issue. The aspect of the search for a causal relationship in international literature has been present for some time.

In recent years, research has mainly focused on the extent to which the degree of internationalisation (DOI) influences corporate performance. Some of these studies suggest that firms, to some extent, preserve the mobility of their resources to achieve economies of scale and exploit imperfections in markets and expand their business opportunities (Chalmers et al., 2020; Gomes \& Ramaswamy, 1999; Steinbruch et al.,2020; Tallamn \& Li, 1966). This theory notes that firms do not become multinational unless there is an opportunity for advantage, so foreign expansion must positively impact firm performance (LópezMorales \& Gómez-Casas, 2015). However, the popularisation of research in this area is becoming a reason to abandon this scientific consensus favouring the many models developed over recent decades. Studies on the impact of internationalisation in British industrial centres have shown a linear convergence between degree of internationalisation (DOI) and company performance with an upward trend (Grant, 1987), which means that a greater DOI generates an increase in economic benefits for companies. Another study presented by Gomes and Ramaswamy (1999) empirically proved that, in fact, between the two coefficients, there is a linear convergence. However, with a negative trend, the DOI, over time, negatively affects productivity, so it remains positive in productivity, but these benefits begin to decrease and are not as great as at the beginning of the international expansion (Gomes \& Ramaswamy, 1999). The dispute about the convergence of the linear impact of internationalisation on firm performance some attempted to overcome by other researchers who argued that this relationship is not linear but Ushaped. However, the empirical re-adaptation of the model showed two faces of this relationship. One, supporters of the U-shaped form of the relationship considered that companies initially represent a negative performance related to the costs of internationalisation, but when internationalisation begins to bring tangible benefits, the trend slowly turns into an increasing relationship (Ruigrok \& Wagner, 2003). The model's shape has been adopted by opponents of this theory, suggesting that the inverted letter " $U$ " fulfils the characteristics of describing economic reality. Basing the thesis on empirical evidence, they suggested that the relationship takes the form of an inverted letter " $U$ " between $\mathrm{DOI}$ and company performance, which means that with time and increasing scale of the degree of internationalisation, the positive impact on the company's performance offsets by the costs of coordinating international operations in different countries (Gomes \& Ramaswamy, 1999).

One of the most significant conclusions from the above models is that internationalisation does impact corporate financial performance. It continues to be an influence that requires further research, whose structure and contingency still elude researchers in its irrevocable form. The corporate performance itself is a construct that results from several not undeviating related factors arising from the company's ventures and external factors. The binary adoption of this relationship is essential because the internationalisation of businesses today is considered a factor in the entity's success. The fact that relational models do not fully explain the phenomenon does not mean that their understanding does 
not affect the decision-making process because just the awareness of this relationship can affect the company's strategy.

\section{RESEARCH METHODOLOGY}

In the literature on the subject, it seems to be gaining popularity to study the impact of the internationalisation of a business unit on its financial performance by comparing the above to the DOI internationalisation scale or the transnationality (TNI) coefficient proposed by UNCTAD (2007). Over many decades of development of the research domain, many researchers have pointed out that the main element for assessing the degree of internationalisation should be the share of foreign sales in the company's total sales (FSTS). Siddharthan and Lall (1982), based on a study of the 100 largest multinational corporations of the United States in terms of firm growth, where they took FSTS as the independent variable, concluded that the degree of internationalisation had a negative impact on the firm's growth rate (Siddharthan \& Lall, 1982). Other researchers, again based on the 100 largest multinational corporations in the United States but enriching the research sample with the 100 largest European corporations, concluded that financial performance improved monotonically with increasing FSTS, but peaked and declined when FSTS exceeded the 60\%-80\% FSTS threshold (Geringer et al., 1989). This conclusion was contrary to the research of Daniels and Bracker (1989), who, based on 116 American multinational corporations, confirmed the thesis on the effect of internationalisation on corporate financial performance, where the researchers designated FSTS as the independent variable. Adopting the share of foreign sales in total sales as the only estimator of the scale of internationalisation DOI seems problematic. Nevertheless, as an external observer, it is not straightforward to obtain the information regarding the company necessary to determine the transnationality index (TNI) or transnational activities spread index (TASI). However, according to the Polish Accounting Act and the Code of Commercial Partnerships and Companies, it is obligated to report revenues from sales of foreign origin, which exhibits ease to convert into a ratio comparing foreign sales to total sales. Consequently, although the practice of using the FSTS indicator is fraught with research uncertainty, it is one of the few pieces of information that a researcher can swiftly obtain at the stage of aggregating a company's financial information; therefore I, emphasising awareness of the problems of using the above indicator, decide to use it in this study.

The evaluation of the impact of this aspect of internationalisation on the company's financial performance will be presented in four financial fields of the company's performance, represented by four groups of financial ratios. At the same time, the study's main objective is the correlational assessment of the relationship between the financial situation represented by the above-mentioned financial ratios and its internationalisation, represented by the FSTS ratio, which is the resultant of the analysed geographical structure of income. Within the framework of the article's primary objective thus formulated, I am articulating a specific objective to verify the economic sense of applying the FSTS indicator in assessing the impact of the company's internationalisation on its financial performance.

The research process for this article involves the verification of the following research hypotheses:

H1: There is a correlation between increasing foreign sales shares in total sales and improving liquidity performance of the firm.

H2: There is a correlation between an increase in the share of foreign sales in total sales and improving the profitability performance of the firm.

H3: There is a correlation between increased foreign sales shares in total sales and a reduction in the firm's debt.

H4: There is a correlation between increasing foreign sales shares in total sales and increasing management efficiency of the firm.

H5: Using the ratio of the share of foreign sales to total sales in determining the impact of internationalisation on a firm's financial performance retains an economic sense.

H6: The degree of internationalisation of a firm (DOI)has a positive impact on its financial position. 
The method used in this study - a case study, applied as a deductive method, will constitute a check or analysis of the relationships between variables, which are the basis of quantitative research methods. Within the framework of the present work, I decided to precisely choose the case study method, thus constituting an analysis of existing statistical data, as it constitutes a systematic procedure implemented to audit the content of recorded information in the form of statistical data, where the source of these data will be the enterprise itself, which is obliged to publish financial statements. In order to verify the research hypotheses, the paper applies the indicator analysis, whose history of application dates back to the second half of the 19th century (Horrigan, 1968) when, along with the development and industrial maturity of the United States, there was a growing demand for solutions in financial mathematics that would make it possible to evaluate a company's economic and financial performance. During the development of this tool, authors of the indicator analysis separated the four most essential elements of a company's financial performance. Using the literature on the subject, calculating tools and my knowledge, I developed eleven indicators that constitute the foundation of the research process presented in this paper, and these are as follows:

I. Financial liquidity ratios: (1) Current ratio, (2) Quick ratio;

II. Profitability ratios: (3) Return on Sales, (4) Return on Assets, (5) Return on Equity;

III. Company debt ratios: (6) Debt ratio, (7) Long-term debt ratio, (8) Long term capital fixed to assets;

IV. Company management efficiency ratios: (9) Total asset turnover, (10) Receivable's turnover in days.

The indicators resulting from the analysis of the company's financial data will be related to the geographical structure of CD Projekt's revenue, thanks to the correlation method proposed by Karl Pearson as follows (Mukaka, 2012):

$$
r=\frac{\operatorname{cov}[X, Y]}{\sigma[X] * \sigma[Y]}
$$

In addition to the sources of statistical data, which are the financial statements of the company CD Projekt from 2010 to 2019 (period of 10 years), published in the court and business monitor, while fulfilling the obligation under the law of the country following the address of the registered office of the company, I will also use the literature on the subject published both in the continuous publication and industry journals.

\section{RESULTS AND DISCUSSION}

\section{Geographical structure of revenue}

One of the elements that do not appear in the literature and the interpretation of the indicator analysis is the analysis of the geographic structure of revenue. It can provide me with knowledge about the possible diversification of the company's sources of income and, what seems essential from the point of view of the subject of this article, some knowledge about the internationalization of the studied company. Given the presented observation, I decide to enrich the analysis with the geographical structure of revenue and the related internationalization index FSTS. The table presents the aggregated geographical structure of revenue of the CD Projekt capital group, for which data I obtained from consecutive consolidated financial statements of the CD Projekt capital Group (Table 1).

\section{Relationship between CD Projekt's liquidity analysis and internationalization}

For an analysis of a company's liquidity, it seems crucial to use factors that reflect the entity's ability to meet its short-term obligations, while relating these values to the changing geographical structure of exports will make it possible to define the correlation between the values indicated, or the lack thereof. The indicators established for this analysis will be (Table 2):

1. Current liquidity ratio $(C R)$, established as the ratio of current assets to current liabilities, informing how many times current assets cover current liabilities.

2. High liquidity ratio $(Q R)$, established as the relation of total assets fewer inventories and prepayments and accruals to current liabilities, which shows the degree to which current liabilities are covered with assets characterized by a high degree of liquidity. 
Table 1. Geographical structure of CD Projekt's revenue between 2010 and 2019

\begin{tabular}{|l|c|c|c|c|c|c|c|c|c|c|}
\hline \multicolumn{1}{|c}{ Place of revenue } & $\begin{array}{c}\mathbf{2 0 1 0} \\
\text { (in \%) }\end{array}$ & $\begin{array}{c}\mathbf{2 0 1 1} \\
\text { (in \%) }\end{array}$ & $\begin{array}{c}\mathbf{2 0 1 2} \\
\text { (in \%) }\end{array}$ & $\begin{array}{c}\mathbf{2 0 1 3} \\
\text { (in \%) }\end{array}$ & $\begin{array}{c}\mathbf{2 0 1 4} \\
\text { (in \%) }\end{array}$ & $\begin{array}{c}\mathbf{2 0 1 5} \\
\text { (in \%) }\end{array}$ & $\begin{array}{c}\mathbf{2 0 1 6} \\
\text { (in \%) }\end{array}$ & $\begin{array}{c}\mathbf{2 0 1 7} \\
\text { (in \%) }\end{array}$ & $\begin{array}{c}\mathbf{2 0 1 8} \\
\text { (in \%) }\end{array}$ & $\begin{array}{c}\mathbf{2 0 1 9} \\
\text { (in \%) }\end{array}$ \\
\hline Local & $\mathbf{7 3 . 6 0}$ & $\mathbf{5 0 . 3 0}$ & $\mathbf{4 6 . 1 0}$ & $\mathbf{4 3 . 7 0}$ & $\mathbf{4 , 3 2}$ & $\mathbf{4 , 6 8}$ & $\mathbf{4 , 5 3}$ & $\mathbf{5 , 2 9}$ & $\mathbf{3 , 4 3}$ & $\mathbf{3 , 3 6}$ \\
\hline Foreign & $\mathbf{2 6 . 4 0}$ & $\mathbf{4 8 . 7 0}$ & $\mathbf{5 3 . 9 0}$ & $\mathbf{5 6 . 3 0}$ & $\mathbf{9 5 . 6 8}$ & $\mathbf{9 5 . 3 2}$ & $\mathbf{9 5 . 4 7}$ & $\mathbf{9 4 . 7 1}$ & $\mathbf{9 5 . 5 7}$ & $\mathbf{9 6 . 6 4}$ \\
\hline Europe */since 2018 only EU & 20.30 & 17.40 & 16.30 & 17.70 & $\mathbf{3 4 . 4 7}$ & $\mathbf{2 4 . 9 4}$ & 26.58 & $\mathbf{2 3 . 8 6}$ & $\mathbf{2 9 . 0 8}$ & 25.25 \\
\hline North America */since 2018 only U.S. & 4.80 & 27.70 & 31.20 & 30.30 & 47.87 & 56.83 & 55.45 & 53.98 & 54.99 & 59.95 \\
\hline South America */until 2018 N/A & - & - & - & - & - & - & - & - & 0.75 & 0.67 \\
\hline Asia */until 2019 USSR + Asia & 0.30 & 1.00 & 2.20 & 2.10 & 2.74 & 7.86 & 8.79 & 10.64 & 8.53 & 8.59 \\
\hline Australia */until 2018 N/A & - & - & - & - & - & - & - & - & 1.98 & 2.06 \\
\hline Africa */until 2018 N/A & - & - & - & - & - & - & - & - & 0.24 & 0.12 \\
\hline Rest */since 2018 N/A & 1.00 & 3.60 & 4.20 & 6.20 & 10.60 & 5.69 & 4.65 & 6.23 & - & - \\
\hline
\end{tabular}

Notes: * - indicates a change in data presentation methodology; N/A - stands as not applicable.

Source: own compilation based on: Consolidated financial statements of CD Projekt Capital Group for 2019 and previous years.

Table 2. Profitability ratios of CD Projekt capital group for the years 2010-2019

\begin{tabular}{|l|c|c|c|c|c|c|r|r|r|r|}
\hline Profitability Analysis & $\mathbf{2 0 1 0}$ & $\mathbf{2 0 1 1}$ & $\mathbf{2 0 1 2}$ & $\mathbf{2 0 1 3}$ & $\mathbf{2 0 1 4}$ & $\mathbf{2 0 1 5}$ & $\mathbf{2 0 1 6}$ & $\mathbf{2 0 1 7}$ & $\mathbf{2 0 1 8}$ & $\mathbf{2 0 1 9}$ \\
\hline CR & 1.05 & 1.74 & 2.48 & 2.70 & 1.98 & 3.67 & 7.85 & 7.68 & 6.23 & 2.65 \\
\hline QR & 0.48 & 0.90 & 1.45 & 1.37 & 0.69 & 3.58 & 7.68 & 7.53 & 6.12 & 2.53 \\
\hline
\end{tabular}

Source: own compilation based on: Consolidated financial statements of CD Projekt Capital Group for 2019 and previous years.

An analysis of the development of liquidity ratios at CD Projekt between 2010 and 2019 shows that the company maintained its financial liquidity throughout the analyzed period. However, in the initial period, i.e., in 2010, the company may have recorded temporary problems with the current payment of liabilities, as the ratio of coverage of liabilities with assets indicates their borderline low levels. In 20112014, the level of financial liquidity was at an almost optimal level; however, in 2015-2018, the company recorded a significant over-liquidity (working capital resources in 2017-2018 exceeded current liabilities by almost eight times), only to approach the optimal level of indicator values again in 2018. Having analyzed the company's financial liquidity, it is worth relating the indicated values to the geographical structure of revenue. The relation will determine how the values of financial liquidity ratios correlate with changes in the company's revenue sources and justify the correlation or lack thereof.

Table 3. Summary of correlations of CD Projekt liquidity analysis indicators to the geographical structure of revenue in the period 2010-2019

\begin{tabular}{|c|c|c|}
\hline Geographical breakdown of revenue & Liquidity indicators & Correlation coefficient value \\
\hline \multirow{2}{*}{ FSTS (Foreign Sales to Total Sales) } & CR (Current Ratio) & 0.6311 \\
\cline { 2 - 3 } & QR (Quick Ratio) & 0.6459 \\
\hline
\end{tabular}

Source: own compilation based on: Consolidated financial statements of CD Projekt Capital Group for 2019 and previous years.

CD Projekt's penetration of the domestic market is so high that to increase cash inflows, the company must expand beyond its home market and broaden its customer base to include foreign customers. This observation seems significant because both the current ratio and the high liquidity ratio show that in CD Projekt, an increasing percentage of export sales correlates highly with an increase in liquidity ratios (Table 3 ), the reason for which is the limited possibility of expanding the customer base in the domestic market. This also means that in the case in question, the increasing DOI (according to the FSTS measure) to a significant extent leads (or, using the literature on the subject directly, "correlates highly") to an improvement in the company's financial liquidity, which allows me to confirm the hypothesis that there is a correlation between the increase in the share of foreign sales in total sales and the improving liquidity results of the company. Especially in the era of digital distribution, where the company does not have to spend money on transporting or packaging the product, the main cost appearing in the product's price is its production cost. Therefore, an increasing volume of sales allows the fixed costs to be spread over a more significant number of copies of the game sold, which affects 
the revenue generated from the sale of products. It is, therefore, reasonable to conclude that in the case of the company in question, its internationalization had a positive impact on its liquidity.

Relationship between CD Projekt's profitability analysis and internationalization

The result of actions determined by effectiveness, efficiency and adaptability is a profitable activity. The usage of these determinants leads to a particular situation. The expected output of it is profitability based not only on the company's specific activities but also on the enterprise. However, the profitability of an enterprise can be evaluated based on the context of the measures used to assess it, focusing on the profitability of sales, assets, or equity involved (Moscviciov et al., 2010). To carry out the analysis, indicators I will apply to present, analyze and evaluate the profitability of CD Projekt in the years 2010-2019. Indicators representing each aspect of profitability will serve this purpose, and they will be as follows (Table 4):

1. Return on Sales (ROS), determined as the percentage of net profit in net sales, showing what profit margin a specific volume of sales brings;

2. Return on Assets (ROA), calculated as a percentage of net profit in the total value of assets, indicating the ability of assets to generate profit, thus providing information on the effectiveness of asset management in the company liquidity;

3. Return on Equity (ROE), determined as the value of net profit concerning the value of equity and expressed as a percentage, provides information on the effectiveness of equity.

Table 4. Profitability ratios of CD Projekt Capital Group for the years 2010-2019

\begin{tabular}{|l|c|c|c|c|c|c|c|c|c|c|}
\hline Profitability analysis & $\mathbf{2 0 1 0}$ & $\mathbf{2 0 1 1}$ & $\mathbf{2 0 1 2}$ & $\mathbf{2 0 1 3}$ & $\mathbf{2 0 1 4}$ & $\mathbf{2 0 1 5}$ & $\mathbf{2 0 1 6}$ & $\mathbf{2 0 1 7}$ & $\mathbf{2 0 1 8}$ & $\mathbf{2 0 1 9}$ \\
\hline ROS & $-6.84 \%$ & $17.30 \%$ & $17.15 \%$ & $10.18 \%$ & $4.86 \%$ & $42.91 \%$ & $42.90 \%$ & $43.24 \%$ & $30.13 \%$ & $33.63 \%$ \\
\hline ROA & $-4.44 \%$ & $19.09 \%$ & $18.56 \%$ & $8.67 \%$ & $2.78 \%$ & $66.66 \%$ & $32.24 \%$ & $22.68 \%$ & $10.90 \%$ & $15.86 \%$ \\
\hline ROE & $-2.06 \%$ & $12.72 \%$ & $13.86 \%$ & $6.65 \%$ & $1.88 \%$ & $51.95 \%$ & $28.63 \%$ & $20.40 \%$ & $9.70 \%$ & $12.49 \%$ \\
\hline
\end{tabular}

Source: own compilation based on: Consolidated financial statements of CD Projekt Capital Group for 2019 and previous years.

The higher the value of the profitability ratios, the more profitable the company's activity is. However, it is difficult to determine their optimum level as absolute values, so the literature on the subject points instead to their assessment through the prism of changes over time, rather than an analysis of specific values somehow separated from the previous ones. An analysis of profitability ratios in CD Projekt Capital Group in the years 2010-2019 emphatically proves the existence of two periods of the company's development - the years 2010-2014 and the years 2015-2019. In the first period indicated, and more specifically its initial year, the company recorded losses, resulting from the costs of sales, overheads, and other operating costs, which absorbed the company's profit. The following years of the period in question saw a definite improvement in the ratios resulting from the release of the company's new product, which had a positive effect on sales, raising the value of the sales profitability ratios to the range of $4.86 \%-17.30 \%$, return on capital to the range of $2.78 \%-19.09 \%$ and return on assets, which was in the range of $1.86 \%-6.65 \%$. In the next separated period, i.e., from 2015 to 2019, the company's profitability results were already characterized by very high profits and thus also by above-average good profitability ratios. In the second period of the company's operations, the ranges of the above were set at levels of $30.13 \%-42.91 \%$ for sales profitability, $10.90 \%-66.66 \%$ for capital profitability and $9.70 \%-51.95 \%$ for asset profitability. Again, as in the case of the liquidity analysis, it is worthwhile to relate the indicated profitability ratios to the geographical revenue structure by determining whether a change in the FSTS ratio and, therefore, a change in the share of foreign sales in total sales, statistically explains the changes in the profitability ratios (Table 5).

The analysis of correlation ratios can begin with the ratio presenting the lowest value, which means a value of 0.4446 for the ROE ratio. According to Pearson's interpretation of the correlation coefficient, in the case of the company CD Projekt in 2010-2019, the increasing percentage of export sales correlates on average with the increase in the return on equity ratio (Table 5). A high value of this ratio also higher capital efficiency, as it creates opportunities to obtain high dividends and allows to use part of the funds for further business development. The increasing value of net profit while 
maintaining the value of capital at the same level will increase the theoretical effectiveness of the company; however, using the correlation index to determine the convergence of changes in the profitability index and changes in the geographical structure of income, certain aspects of the company's activity should not be overlooked. It can be observed, when analyzing operations on the company's capital, that activities that cause a decrease in the value of the return on equity ratio positively affect the capital structure, increasing the share of equity in the total capital, thus reducing the financial leverage, and thus have their positive impact on the valuation and profitability of the company. Therefore, the correlation between ROE and the geographical structure of income exists and is observable. However, apart from increasing net profits, the stock company performs several activities and operations, not observable within the correlation indicator, which has its own financial or accounting justification but negatively influences the correlation coefficient.

Table 5. Summary of correlations of CD Projekt profitability analysis indicators to the geographical structure of revenue in the period 2010-2019

\begin{tabular}{|c|c|c|}
\hline Geographical breakdown of revenue & Profitability indicators & Correlation coefficient value \\
\hline \multirow{2}{*}{ FSTS (Foreign sales to total sales) } & ROS (Return on Sales) & 0.5020 \\
\cline { 2 - 3 } & ROA (Return on Assets) & 0.4446 \\
\cline { 2 - 3 } & ROE (Return on Equity) & 0.4779 \\
\hline
\end{tabular}

Source: own compilation based on: Consolidated financial statements of CD Projekt Capital Group for 2019 and previous years.

A further consideration in discussing the correlation values of the geographical composition of revenue and ROA is that the use of a correlation as simple as Pearson's coefficient does not consider an essential piece of information for the analysis, the volume of foreign trade. Profits from abroad lag the share of the revenue from abroad in the geographical structure at specific points. The situation is quite the opposite when the discussed geographical structure is related to the Return on Sales, which shows a very high correlation, and which can be interpreted as the fact that the increasing percentage of foreign sales in total sales has a direct impact on the increase in the return on sales ratio. That confirms the hypothesis, which assumed a correlation between increasing foreign sales shares in total sales and improving the company's profitability results. This effect is related to the fact that foreign markets are potentially more absorptive, even with a low penetration level, than domestic markets, as proven by the economies of scale theory. The export development of the publishing studio CD Projekt was directly linked to opening to foreign markets characterized by a much greater capacity than the domestic market. Therefore, in the case of the company in question, the thesis that increasing the share of the revenue from export sales in the geographical structure of revenue is associated with an increase in sales profitability is justified.

\section{Relationship between CD Projekt's debt analysis and internationalization}

Even companies unrivalled industry leaders and the largest private entity listed on the Warsaw Stock Exchange in terms of accumulated assets cannot rely solely on equity. The main objective of a debt analysis is to determine the level and structure of a company's external capital by verifying whether the level of external capital threatens the company's financial independence (Gabrusewicz, 2014). The desired effect of this analysis is to determine whether the company can pay its long-term debts within a certain period and in a certain amount. As part of the debt analysis, the following measures will be indicated and calculated (Table 6):

1. Debt ratio (DR, from Debt ratio) as the ratio of total liabilities and provisions for liabilities to total assets of the company, informing mainly about the importance of foreign capital in financing the company's assets (Wach, 2017);

2. Long-term debt ratio (LTDR) as a relation of long-term debt to equity, expressed as a percentage, informs about the burden of equity with external, long-term forms of financing;

3. Long term capital to assets ratio (LTCFA), as a ratio of equity to fixed assets, informing about the degree of financial independence by measuring the share of financing assets with equity. 
Table 6. Debt ratios of CD Projekt Capital Group for the years 2010-2019

\begin{tabular}{|l|c|c|c|c|c|c|c|c|c|c|}
\hline \multicolumn{1}{|c|}{ Debt analysis } & $\mathbf{2 0 1 0}$ & $\mathbf{2 0 1 1}$ & $\mathbf{2 0 1 2}$ & $\mathbf{2 0 1 3}$ & $\mathbf{2 0 1 4}$ & $\mathbf{2 0 1 5}$ & $\mathbf{2 0 1 6}$ & $\mathbf{2 0 1 7}$ & $\mathbf{2 0 1 8}$ & $\mathbf{2 0 1 9}$ \\
\hline DR & 0.54 & 0.33 & 0.25 & 0.23 & 0.33 & 0.22 & 0.11 & 0.10 & 0.11 & 0.21 \\
\hline LTDR & $9.53 \%$ & $4.10 \%$ & $3.75 \%$ & $2.38 \%$ & $0.86 \%$ & $0.55 \%$ & $0.95 \%$ & $0.42 \%$ & $0.59 \%$ & $1.79 \%$ \\
\hline LTCFA & 1.04 & 1.44 & 1.69 & 1.81 & 1.82 & 3.75 & 4.60 & 3.47 & 2.55 & $1, .67$ \\
\hline
\end{tabular}

Source: own compilation based on: Consolidated financial statements of CD Projekt Capital Group for 2019 and previous years.

In the case of the general debt ratio, i.e., the ratio of external capital and provisions for liabilities to total company assets, the expected value, according to the literature, should not exceed $50 \%$. Some theoreticians assume that values in the range of 0.57-0.67 constitute the upper, safe limit of this measure. When analyzing the value of the available debt ratio at CD Projekt in the period under analysis, only the initial period, i.e., 2010, raises some concerns. The value of 0.54 approached the upper limit of safe debt but decreased with time, which may indicate the decreasing involvement of debt capital as a form of financing the company's activity, which translates into a permanent decrease in investment risk and an improvement in the company's creditworthiness. However, during the period under review, a noticeable increase in the ratio in 2014 at a level of almost 50\%, from a ceiling of 0.23 to 0.33. Perhaps the studio was looking for external sources of financing to complete the project. It might have also prepared for the release of the product by entering contracts before its completion. Another explanation seems to be that the company preferred to operate with someone else's capital, which was losing value over time, rather than with its capital, which brought the company tangible profits, and the whole process did not have a significant impact on the company's debt level (Table 6).

Table 7. Summary of correlations of CD Projekt debt analysis indicators to the geographical structure of revenue in the period 2010-2019

\begin{tabular}{|c|l|c|}
\hline Geographical breakdown of revenue & \multicolumn{1}{|c|}{ Debt indicators } & Correlation coefficient value \\
\hline \multirow{3}{*}{ FSTS (Foreign sales to total sales) } & DR (Debt Ratio & -0.7666 \\
\cline { 2 - 3 } & LTDR (Long Term Debt Ratio) & -0.9063 \\
\cline { 2 - 3 } & LTCFA (Long Term Capital Fixed to Assets) & 0.6631 \\
\hline
\end{tabular}

Source: own compilation based on: Consolidated financial statements of CD Projekt Capital Group for 2019 and previous years.

The first index representing the lowest level of correlation is the equity to fixed assets ratio coefficient, which was at the level of 0.6631 , which in the light of interpretation means high correlation. The relatively low correlation coefficient can be explained by the fact that changes in capital value occur in a different period than changes in the geographical structure of income. A different situation occurs in the case of the general debt ratio. Here correlation with the geographical structure and revenue from 2010 to 2019 was -0.7666 . Interpreting the above value, that can be concluded that the increasing percentage value of export sales correlates very highly with the decrease in the general debt ratio.

On the one hand, this indicator shows a very high correlation (Table 7), but on the other hand, a specific dependence can be observed, the awareness of which explains the appropriately lower than expected value of the correlation. The degree of overlap is not close to the unit value because it is more economical for a company to acquire free capital from customers who are ready to pay for a product that in principle does not exist yet than to use its capital, which in the meantime, thanks to mechanisms such as $\mathrm{O} / \mathrm{N}$ deposits (Overnight Deposit) generates real profit for the entity. The value of the indicator will never indicate an almost certain correlation in a situation in which the company behaves economically, which is understood by looking for the cheapest and lowest-risk forms of financing, and indebtedness generated as an advance from customers, which is capital with basically no costs and does not represent any significant risk. The last correlation coefficient represents an extremely high level and is the correlation coefficient of changes in the geographic structure of revenue and the long-term debt ratio. According to the interpretation of the coefficient, an increasing percentage of export sales almost certainly correlates with a decrease in the long-term debt ratio, which can 
be explained by the fact that exports made it possible to generate more and more profits from operations, as shown in the profitability analysis. In the case of CD Projekt, the hypothesis presented by me in the introduction can therefore be accepted that there is a correlation between the increase in the share of foreign sales in total sales and a decrease in the indebtedness of the company.

\section{Relationship between CD Projekt's management efficiency analysis and internationalization}

The last of the stages of evaluating a company from a financial point of view in the framework of ratio analysis is the analysis of the company's management efficiency, i.e., the translation of the company's skills and capabilities into financial language, through a series of values determining the efficiency of using the company's resources in the realities of the economic environment. Within the analysis framework, I will use two indicators, in my opinion, important from the analysis point of view, which belongs to the group of rotational indicators. Using them, he will establish basic information about the efficiency of CD Projekt's enterprise management in the years 2010-2019 and interpret this information. These will be (Table 8):

1. Asset turnover ratio (TAT), created based on the comparison of net sales revenues to total assets, which informs what part of the company's assets was covered by the profit of a given accounting period;

2. Receivables turnover ratio in days (RT), created based on the average level of trade receivables to total sales revenue, multiplied by the number of days in the accounting period, inform the number of days in which the company's financial resources are frozen in receivables.

Table 8. CD Projekt Capital Group's business management efficiency indicators for the years 2010-2019

\begin{tabular}{|c|c|c|c|c|c|c|c|c|c|c|}
\hline Efficiency analysis & 2010 & 2011 & 2012 & 2013 & 2014 & 2015 & 2016 & 2017 & 2018 & 2019 \\
\hline TAT & 0.30 & 0.74 & 0.81 & 0.65 & 0.39 & 1.21 & 0.67 & 0.47 & 0.32 & 0.37 \\
\hline RT & - & 67.17 & 70.66 & 62.01 & 44.51 & 21.52 & 49.78 & 46.42 & 41.88 & 58.32 \\
\hline
\end{tabular}

Source: own compilation based on: Consolidated financial statements of CD Projekt Capital Group for 2019 and previous years.

The TAT ratio indicates the ratio of the company's net profit to the assets that generated this profit, and its value was very high for CD Projekt between 2010 and 2019. The beginning of the examined period, i.e., 2010, was objectively the weakest period in terms of the company's asset turnover, reaching a value of 0.3 (Table 8), which translates into information that the assets accumulated by the company allowed it to generate $30 \%$ of its value in net profit. Subsequent years, and therefore subsequent products of the studio, increased this measure accordingly. Analyzing the values of the RT indicator, one can notice the initially long period of waiting for repayment of debts among creditors, which from 2011 to 2013 did not fall below two months. The following two years saw an improvement in collecting debts in 2014 at 45 days and 2015 at the lowest level -22 days. After 2015, the values returned to a level above 40 days, with a peak in 2019 of 58 days (Table 8).

Table 9. Summary of correlations of indicators of CD Projekt's management efficiency analysis to the geographical structure of revenue in the period 2010-2019

\begin{tabular}{|c|l|c|}
\hline Geographical breakdown of revenue & \multicolumn{1}{|c|}{ Management efficiency indicators } & Correlation coefficient value \\
\hline \multirow{2}{*}{ FSTS (Foreign Sales to Total Sales) } & TAT (Total Asset Turnover) & 0.0289 \\
\cline { 2 - 3 } & RT (Receivable turnover in days) & -0.7501 \\
\hline
\end{tabular}

Source: own compilation based on: Consolidated financial statements of CD Projekt Capital Group for 2019 and previous years.

Starting from the value of the RT indicator, an interesting correlation can be observed, which boils down to the interpretation that an increasing percentage of export revenues in total revenues correlates highly with an increase in the value of trade receivables turnover in days (Table 9). The conclusion that can be drawn from the value of the correlation indicator is that the company, along with the increase in international importance and improvement of its competitiveness, shortened the receivables turnover period, requiring contractors to pay receivables in shorter periods. The second of the indicators of the company's management efficiency presented in the table above, i.e., the correlation index of the company's asset turnover and the geographic structure of its revenue, almost shows no 
signs of linear correlation (Table 9). That can be concluded with the observation that the company's asset profitability is not related to the changing geographic structure in a linear way, which allows only partial confirmation of the hypothesis that there is a correlation between the increase in the share of foreign sales in total sales and the increasing management efficiency of the company.Table 10 presents the summary of the verifications of all six research hypotheses presented in this article.

Table 10. Verifications of all six research hypotheses

\begin{tabular}{|l|l|c|}
\hline No. & \multicolumn{1}{|c|}{ Hypotheses } & Result \\
\hline H1: & $\begin{array}{l}\text { There is a correlation between increasing foreign sales shares in total sales (FSTS) and improv- } \\
\text { ing liquidity performance of the firm. }\end{array}$ & Confirmed \\
\hline H2: & $\begin{array}{l}\text { There is a correlation between an increase in the share of foreign sales in total sales (FSTS) } \\
\text { and improving the profitability performance of the firm. }\end{array}$ & Confirmed \\
\hline H3: & $\begin{array}{l}\text { There is a correlation between increased foreign sales shares in total sales (FSTS) and a reduc- } \\
\text { tion in the firm's debt. }\end{array}$ & Confirmed \\
\hline H4: & $\begin{array}{l}\text { There is a correlation between increasing foreign sales shares in total sales (FSTS) and increas- } \\
\text { ing management efficiency of the firm. }\end{array}$ & Confirmed \\
\hline H5: & $\begin{array}{l}\text { Using the ratio of the share of foreign sales to total sales (FSTS) in determining the impact of } \\
\text { internationalisation on a firm's financial performance retains an economic sense. }\end{array}$ & Confirmed \\
\hline H6: & The degree of internationalisation of a firm (DOI) has a positive impact on its financial position. & Confirmed \\
\hline
\end{tabular}

Source: own study.

\section{CONCLUSIONS}

The result of the study is undoubtedly the confirmation of the thesis of preserving the economic sense of using the FSTS index in the study of the impact of the company's internationalisation on its financial performance. The specific objective of the preceding article was to assess the effects of the internationalisation process of the company on its financial position, and I achieved this objective, which confirms, according to the principle of deductive reasoning, that the assessment of the impact of the internationalisation process of the company made based on the FSTS indicator retains the economic sense. The study's primary objective was also, thanks to the research presented in this paper, achieved, resulting in the confirmation of the sixth hypothesis, if the internationalisation of the company has a positive impact on its financial position.

As part of the analytical process, thanks to the presentation of output data proving that the company CD Projekt is internationalised and that the change in the value of the company's financial indicators to a certain extent, currently exposed in the correlation statistics, was intimated by changes in the geographical structure of income, it is reasonable to conclude following the derivation rule that the internationalisation of the company discussed in the case study had its desired effect on its financial performance. Based on the analysis of statistical data and case study analysis, the result of the conducted research is the verification of my detailed hypotheses with the result of the study.

In this paper, the only one video game company was presented and discussed (as the case study); however, the noticed trend seems to be maintained within the whole industry. Therefore, there is an obvious need for further attempts to study the impact of internationalization on companies' financial performance within the creative industry. It seems that the video game industry reveals a propensity to internationalize. Therefore, further studies are needed. Since the study presented in this paper was limited to only one sample company (a case study method), the output data does not represent the entire industry (lack of representativeness), but it encourages further exploration of the topic and expand the research, which I strongly recommend. 


\section{REFERENCES}

Ahroni, Y. (1966). The Foreign Investment Decision Process. Boston: Division of Reaserch, Graduate School of Business Administration.

Barłożewski, K., \& Trąpczyński, P. (2021). Internationalisation motives and the multinationality-performance relationship: The case of Polish firms. Entrepreneurial Business and Economics Review, 9(2), 85-104. https://doi.org/10.15678/EBER.2021.090206

Chalmers, D., Manetta, E.,\& Sensini, L. (2020). R\&D and internationalization: Efect on the Performance of SMEs. International Journal of Advances in Management and Economics, 9(3), 39-48. https://doi.org/10.31270/IJAME/v09/i03/2020/5

Cushman \& Wakefield LLP (2016). Where in the world: Business processoutsourcing and share service location index 2016. QBusiness.pl. Retrieved from https://www.qbusiness.pl/uploads/Raporty/cwbpo2016.pdf

Daniels, J.D., \& Bracker, J. (1989). Profit performance: Do foreign operations make a difference? Management International Review, 1(29), 46-56.

Gabrusewicz, W. (2014). Analiza finansowa przedsiębiorstwa. Teoria i zastosowanie. Warszawa: PWE.

Geringer, J.M., Beamish, P.W.,\& DaCosta, R.C. (1989). Diversification strategy and internationalization: Implications for MNE performance. Strategic Management Journal, 2(10), 10-19. https://doi.org/10.1002/smj.4250100202

Global Enterpreneurship Monitor (2021). 2020/2021 Global Report. London: Global Enterpreneurship Research Association.

Gomes, L., \& Ramaswamy, K. (1999). An empirical examination of the form of the Relationship beteen multinationality and performance. Journal of International Business Studies, 1(30), 173-188. https://doi.org/10.1057/palgrave.jibs.8490065

Graham, B., \&Dodd, D. (2009). Security Analysis. New York: Mc Graw Hill.

Grant, R.M. (1987). Multinationality and performance among British manufacturing companies. Journal of International Business Studies, 3(18), 79-89. https://doi.org/10.1057/palgrave.jibs.8490413

Horrigan, J.O. (1968). A Short Story of Financial Ratio Analysis. The Accounting Review,2(43), 284-294.

https://www.jstor.org/stable/243765

Jung, J.,\& Bansal, P. (2009). How Firm Performance Affects Internationalization. Management International Review, 6(49), 711. https://doi.org/10.1007/s11575-009-0014-7

Kahneman, D., \& Tversky, A. (1979). Prospect Theory: An Analysis of Decisions under Risk. Econometrica, 2(47), 263-292. https://doi.org/10.2307/1914185

Ketels, Ch. (2016). Review of Competitiveness Frameworks: An Analysis Conducted for the National Competitiveness Council. Dublin: National Cometitiveness Council.

López-Morales, J.,\& Gómez-Casas, M. (2015). Degree of Internationalization (DOI) and Performance Relationship: An Empirical and Conceptual Approach. International Journal of Academic Reaserch in Business and Social Sciences, 4(9), 39-56. http://dx.doi.org/10.6007/IJARBSS/v4-i9/1128

Maciejewski, M., \& Głodowska, A. (2020). Economic development versus the growing importance of the financial sector: Global insight. International Entrepreneurship Review, 6(3), 77-90.

https://doi.org/10.15678/IER.2020.0603.06

Moscviciov, L., Batrancea, M., Batrancea, I., \& Batrancea, A. (2010). Financial ratio analysis used in the enterprises. Annals of the University of Oradea: Economic Science, 2(1), 600-603.

Mukaka, M.M. (2012). Statistic Corner: A guide to appropriate use of Correlation coefficient in medical reaserch. Malwi Medical Journal, 24(3), 69-71.

Ruigrok, W., \& Wagner, H. (2003). Internationalization and Performance: An Organizational Learning. Perspective. Management International Review, 43(1), 63-83.

Rymarczyk, J. (2020). Technologies, Opportunities and Challenges of the Industrial Revolution 4.0: Theoretical Considerations. Entrepreneurial Business and Economics Review, 8(1), 185-198. https://doi.org/10.15678/EBER.2020.080110

Siddharthan, N.S., \& Lall, S. (1982). Recent growth of the largest U.S. multinationals. Oxford Bulletin of Economis and Statistics, 1(44), 1-13. https://doi.org/10.1111/j.1468-0084.1982.mp44001001.x 
Steinbruch, F., Nunes, M., \& Nascimento, L. (2020). Companies' performance on the internationalization process. Revista Pensamento Contemporâneoem Administração, 14(1), 34-55. https://doi.org/10.12712/rpca.v14i1.38441

Tallman, S., \& Li, J. (1996). Effects of International Diversity and Product Diversity on the Performance of Multinational Firms. The Academy of Management Journal, 39(1),179-196.

https://doi.org/10.1111/j.1468-0084.1982.mp44001001.x

Trąpczyński, P., \& Halaszovich, T. (2021). Exploitation-exploration balance and its performance outcomes: A study of FDI portfolio decisions of new multinational. Entrepreneurial Business and Economics Review, 9(4), 115129. https://doi.org/10.15678/EBER.2021.090408

UCTAD (2007). The Diverse of the Largest Transmnational Corporations. New York and Geneva: United Nations.

Wach, K. (2016). Innovative Behaviour of High-Tech Internationalized Firms: Survey Results from Poland. Entrepreneurial Business and Economics Review, 4(3), 153-165. https://doi.org/10.15678/EBER.2016.040311

Wach, K. (2017). Exploring the Role of Ownership in International Entrepreneurship: How does Ownership Affect Internationalisation of Polish Firms? Entrepreneurial Business and Economics Review, 5(4), $205-224$. https://doi.org/10.15678/EBER.2017.050410

Wach, K. (2021). The evolution of the Uppsala model: Towards non-linearity of internationalization of firms. International Entrepreneurship Review, 7(2), 7-19. https://doi.org/10.15678/IER.2021.0702.01

\section{Author}

\section{Sławomir Szwajkosz}

Bachelor in international economics, specialized in international trade from Cracow University of Economics (Poland, 2021). Currently a master student of financial markets as well as international trade at the same university. Correspondence to: Mr. Sławomir Szwajkosz, e-mail: sl.szwajkosz@gmail.com ORCID (1) http://orcid.org/0000-0001-7714-3163

\section{Acknowledgements and Financial Disclosure}

The article is a result of the bachelor thesis written in the years 2020-2021 within international economics (MSG) major and international trade (HZ) specialization under the supervision of prof. dr hab. Krzysztof Wach. The author would like to thank the anonymous referees for their useful comments, which allowed to increase the value of this article.

\section{Conflict of Interest}

The author declares that the research was conducted in the absence of any commercial or financial relationships that could be construed as a potential conflict of interest.

\section{Copyright and License}

This article is published under the terms of the Creative Commons Attribution - NoDerivs (CC BY-ND 4.0) License http://creativecommons.org/licenses/by-nd/4.0/ 
